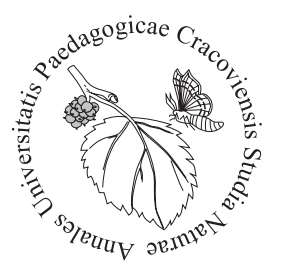

S. Suresh Ramanan ${ }^{1}$, Anatoliy A. Khapugin²*

${ }^{1}$ Kerala Agricultural University KAU, College of Forestry, P.O Vellanikkara, Thrissur, 680656 Kerala, India ${ }_{2}^{2} J o i n t$ Directorate of the Mordovia State Nature Reserve and National Park "Smolny”, Republic of Mordovia, 430011 Saransk, Russia, *hapugin88@yandex.ru.

\title{
Activity of the Intergovernmental Science-Policy Platform on Biodiversity and Ecosystem Services for biodiversity conservation
}

The efforts of scientists to create environmental awareness among the policy makers as well as the public were started during the beginning of $19^{\text {th }}$ century. Globally, this awareness among people and subsequent changes in the climate and the natural phenomenon made policy makers and politicians more action oriented. One of such great effort taken is the foundation of Intergovernmental Panel on Climate Change in 1988 (hereafter - IPCC). It is an organisation that was awarded Nobel Prize in 2007 for its action and efforts. Furthermore, its reports and publications are well acknowledged and recognised politically as well as scientifically (Smith et al., 2009; Howarth et al., 2017). The reports are mainly based on works that are already published. Reports of this sort have great significance and the efforts behind them have to be appreciated.

Notwithstanding the due importance of climate change, biodiversity is not a lesser item on the table which needs great attention. Besides, it is well-known that mitigation efforts on climate change do help in biodiversity conservation as an indirect reaction (Burch et al., 2014; Viña et al., 2016). With the distance between the continents being getting reduced, societies have merged together. This leads to an increased exchange of biological diversity between countries (van Kleunen et al., 2015). For instance, the most of the vegetables on our dining table have reached us far from their centre of origin (Vavilovs centres of origin) (Vavilov, 1927). This is a real example for exchange in local biodiversity. Not only plants, even animals and insects (Hilton, Cuthbert, 2010; Liebhold et al., 2016) are being exchanged, domesticated and introduced in places far from their centres of origin or its natural habitat. The main motivation for this introduction is the benefits that are derived out of the introduced plants or animals. However, the impact of non-native organisms on the local biological diversity and the environment vary depending on species. History has many examples of the negative 
impacts caused by the introductions which became an invasive species. Lantana camara L. (Sharma et al., 2005), Eichhornia crassipes (Mart.) Solms (Villamagna, Murphy, 2010), Opuntia humifusa (Raf.) Raf. (Dean, Milton, 2000; Fateryga, Bagrikova, 2017) are some worldwide examples. Globally, the list of invasive organisms is very exhaustive, which is prepared by the International Union for Conservation of Nature Invasive Species Specialist Group. The article in Science journal (Stokstad, 2017) begins with one such example of South American Coatil (Nasua nasua L.), which a species that was introduced as a pet in Chile and has caused damage to a greater extent. These global examples mentioned above underline the need for understanding the biodiversity in order to avoid the catastrophic biodiversity loss. Further, it is human nature to follow the path of successful personalities (Reis et al., 2000). The identical phenomenon did happen in the case of IPCC too.

\section{Development of Intergovernmental Science-Policy Platform on Biodiversity and Ecosystem Services (IPBES)}

There is clear scientific evidence that we are on the verge of a major biodiversity crisis. Practically all facets of biodiversity are in sharp decline (Johnson et al., 2017). To date, biodiversity decline is still being unrecognised, and this issue is not receiving proper focus in public resolutions. This argument has been put forward by many scientists all over the world. Yet still, Loreau et al. (2006) brought out the paper titled as "Diversity without representation". It details the crux of the need for an international expert panel for biodiversity conservation, which should be more complex than existing one for climate change (IPCC). The paper also details the activities that led to the formation of Intergovernmental Science-Policy Platform on Biodiversity and Ecosystem Services (hereafter - IPBES).

The real development of the IPBES started once the biodiversity loss was highlighted in The Millennium Ecosystem Assessment Report (Larigauderie, Mooney, 2010). In the meantime, a major conference of UNESCO was held in France during 2005 entitled as "Biodiversity: Science and Governance" (Barbault, Le Duc, 2005). During this conference, there was a call for an intergovernmental panel on biodiversity with a similar mechanism to that of the IPCC. This conference produced two documents, the "Paris Declaration on Biodiversity" and a Conference Statement. The Paris declaration proposed an international mechanism including all governmental and non-governmental institutions into an expert panel on biodiversity. As a follow-up, the French government launched the International Mechanism of Scientific Expertise on Biodiversity (hereafter - IMoSEB). This was finally revamped into an international science-policy interface, which was intergovernmental and also included many non-governmental stakeholders after the Montpellier recommendation. 
In April 2008, representatives of the IMoSEB Consultation and Global Strategy for the follow-up to the Millennium Ecosystem Assessment met in Paris (France). It was decided to merge these two initiatives in order to the support discussions on an "Intergovernmental Science-Policy Platform on Biodiversity and Ecosystem Services". Shortly afterwards, the Conference of the Parties was been held (May 2008, Bonn, Germany), where a joint concept on the goals and modalities for IPBES was presented.

In meantime, 2008, the United Nations Environment Programme (hereafter UNEP) organised the first intergovernmental and multi-stakeholder meeting in $\mathrm{Pu}$ trajaya (Malaysia), where the mechanism of interface for biodiversity and ecosystem services was discussed. The next meeting was held in Nairobi (Kenya, 2009), which was attended by 225 delegates from 95 countries and numerous organisations. Thus, the interest for IPBES in the science-policy community was clearly demonstrated. The third intergovernmental and multi-stakeholder meeting was organised in South Korea in 2010, followed by the first plenary meeting on IPBES in Nairobi in 2011, where the platform's modalities and institutional arrangements were framed. During the second plenary meeting in Panama City (2012), a full-fledged platform was established (Larigauderie, Mooney, 2010).

\section{Current achievements and non-recognition of IPBES}

The current structure and functions of the IPBES are well detailed in their official website (http://www.ipbes.net). The output from this institution looks very remarkable. Indeed, the first report on Thematic Assessment of Pollinators, Pollination, and Food Production has incorporated more 3000 research papers. It has been highly appreciated by the policy makers as well as the scientific community (e.g., Potts et al., 2016). The second report of IPBES was the methodological assessment report on scenarios and models of biodiversity and ecosystem services (IPBES, 2016), which were also applauded globally. Currently, the sphere of IPBES activity is still wider. Besides keeping records and assessing the biodiversity trends, it also categorises real-world policy constraints in conservation issues. It also helps in the capacity building of governments and others. The IPBES has employed over 1300 professionals to contribute in its two assessments reports. Similar to IPCC and others international panels like International Assessment of Agricultural Knowledge, Science and Technology for Development, it does not conduct any research nor does it monitor climate related data or parameters. However, there were critical opinions on IPBES work in the scientific community. For example, Turnhout et al. (2012) have indicated some omissions in the IPBES work and suggested nine recommendations for the improvement of IPBES efficiency. They have suggested that the IPBES must focus on a much broader range of knowledge and stakeholders. But, as we see today, the IPBES uses the policy of attracting of external 
specialists to participate in the external review of the IPBES regional assessments of biodiversity and ecosystem services (Larigauderie, Watson, 2017).

Where is support at a difficult time?

Although IPBES performance is impressive, it has some problems. Stokstad (2017) in his article "UN biodiversity group confronts cash crunch" presents a clear picture on the current state of IPBES. The author presents data that clearly indicates that the financial status of the IPBES is in an unfortunate condition. As a result, three major assessment reports have been delayed. One of the reports is on controlling invasive species; secondly, it is on the sustainable use of wild species; thirdly, it is on the cultures perspectives of ecosystem services and the quantification of ecosystem services. This delay is mainly due to the financial issues. Furthermore, it resulted in the reduction in the IPBES annual budget by $8 \%$ (to $\$ 8.7$ million) in 2017 , and it has been decided to cut this budget to $\$ 5$ million (by $30 \%$ ) in 2018. As a result, some processes in the algorithm of biodiversity assessment and ecosystem services are delayed. As Stokstad (2017) rightly noted, many members have reflected on this situation. Unfortunately, there are many cases with similar situations where impressive results are welcome and highly appreciated, but there is a lack or even the absence of appropriate financial support from a state (Pei et al., 2012; Rybakova, 2013; Editorial, 2016).

Conclusions

All these cases clearly indicate that governments, the private sector, and civil societies all over the world want more robust information on reasonable futures for biodiversity and ecosystem services. They want to know how the drivers are impacting biodiversity and ecosystem services that might undergo a dramatic change in the upcoming years. They also want to comprehend the repercussions of different policy choices on biodiversity and ecosystem services, and how to achieve policy targets, e.g., the Aichi targets. Despite these numerous desires, they are all reluctant to fund it. The concern about the economic situation in a country should not hide the problem of environmental quality and nature conservation. The greatest threat is that the decline in public funding for scientific research and organisation, such as IPBES, will have an impact on the research quality. Of course, we do not call for funding of every organisation. We say that appropriate funding must be provided to those who provide the relevant results.

We would like to end by words of Mahatma Gandhi: The world has enough for everyone's need but not enough for everyone's greed. 
The authors would like to thank the two anonymous reviewers whose comments and recommendations have contributed to improving this paper.

\section{References}

Barbault, R., Le Duc, J.P. (2005). Proceedings of the International Conference "Biodiversity: Science and Governance". Paris: Muséum national d'Histoire naturelle.

Burch, S., Berry, P., Sanders, M. (2014). Embedding climate change adaptation in biodiversity conservation: A case study of England. Environmental Science \& Policy, 37, 79-90. DOI: 10.1016/j.envsci.2013.08.014

Dean, W.R.J., Milton, S.J. (2000). Directed dispersal of Opuntia species in the Karoo, South Africa: are crows the responsible agents? Journal of Arid Environments, 45(4), 305-314. DOI: 10.1006/ jare.2000.0652

Editorial (2016). Private funding for science. Nature Methods, 13, 537. DOI: 10.1038/nmeth.3923

Fateryga, V.V., Bagrikova, N.A. (2017). Invasion of Opuntia humifusa and O. phaeacantha (Cactaceae) into plant communities of the Karadag Nature Reserve. Nature Conservation Research, 2(4), 26-39. DOI: $10.24189 /$ ncr.2017.011

Hilton, G.M., Cuthbert, R.J. (2010). The catastrophic impact of invasive mammalian predators on birds of the UK Overseas Territories: a review and synthesis. Ibis, 152(3), 443-458. DOI: 10.1111/j.1474919X.2010.01031.x

Howarth, C., Viner, D., Dessai, S., Rapley, C., Jones, A. (2017). Enhancing the contribution and role of practitioner knowledge in the Intergovernmental Panel on Climate Change (IPCC) Working Group (WG) II process: Insights from UK workshops. Climate Services, 5, 3-10. DOI: 10.1016/j. cliser.2017.04.003

IPBES (2016). The methodological assessment report on scenarios and models of biodiversity and ecosystem services. In: S. Ferrier, K.N. Ninan, P. Leadley, R. Alkemade, L.A. Acosta, H.R. Akçakaya, L. Brotons, W.W.L. Cheung, V. Christensen, K.A. Harhash, J. Kabubo-Mariara, C. Lundquist, M. Obersteiner, H.M. Pereira, G. Peterson, R. Pichs-Madruga, N. Ravindranath, C. Rondinini, B.A. Wintle (eds.). Secretariat of the Intergovernmental Science-Policy Platform on Biodiversity and Ecosystem Services. Bonn: IPBES.

Johnson, C.N., Balmford, A., Brook, B.W., Buettel, J.C., Galetti, M., Guangchun, L., Wilmshurst, J.M. (2017). Biodiversity losses and conservation responses in the Anthropocene. Science, 356(6335), 270-275. DOI: 10.1126/science.aam9317

Larigauderie, A., Mooney, H.A. (2010). The Intergovernmental science-policy Platform on Biodiversity and Ecosystem Services: moving a step closer to an IPCC-like mechanism for biodiversity. Current Opinion in Environmental Sustainability, 2(1), 9-14. DOI: 10.1016/j.cosust.2010.02.006

Larigauderie, A., Watson, R.T. (2017). IPBES calls for peer review of its draft assessments. Nature Ecology and Evolution, 1(6), 164. DOI: 10.1038/s41559-017-0164

Liebhold, A.M., Yamanaka, T., Roques, A., Augustin, S., Chown, S.L., Brockerhoff, E.G., Pyšek, P. (2016). Global compositional variation among native and non-native regional insect assemblages emphasizes the importance of pathways. Biological Invasions, 18(4), 893-905. DOI: 10.1007/s10530-016-1079-4

Loreau, M., Oteng-Yeboah, A., Arroyo, M.T.K., Babin, D., Barbault, R., Donoghue, M., Gadgil, M., Häuser, C., Heip, C., Larigauderie, A., Ma, K. (2006). Diversity without representation. Nature, 442(7100), 245-246. DOI: $10.1038 / 442245$ a

Pei, L., Gaisser, S., Schmidt, M. (2012). Synthetic biology in the view of European public funding organisations. Public Understanding of Science, 21(2), 149-162. DOI: 10.1177/0963662510393624 
Potts, S.G., Imperatriz-Fonseca, V., Ngo, H.T., Aizen, M.A., Biesmeijer, J.C., Breeze, T.D., Dicks, L.V., Garibaldi, L.A., Hill, R., Settele, J., Vanbergen, A.J. (2016). Safeguarding pollinators and their values to human well-being. Nature, 540(7632), 220-229. DOI: 10.1038/nature20588

Reis, H.T., Collins, W.A., Berscheid, E. (2000). The relationship context of human behaviour and development. Psychological Bulletin, 126(6), 844-872.

Rybakova, L.I. (2013). State Scientific and Technological Policy and Financing of Science (Experience 2000-2012). Science. Innovation. Education, 14, 151-174. [In Russian]

Sharma, G.P., Raghubanshi, A.S., Singh, J.S. (2005). Lantana invasion: an overview. Weed Biology and Management, 5(4), 157-165. DOI: 10.1111/j.1445-6664.2005.00178.x

Smith, J.B., Schneider, S.H., Oppenheimer, M., Yohe, G.W., Hare, W., Mastrandrea, M.D., Patwardhan, A., Burton, I., Corfee-Morlot, J., Magadza, C.H., Füssel, H.M. (2009). Assessing dangerous climate change through an update of the Intergovernmental Panel on Climate Change (IPCC) "reasons for concern". Proceedings of the National Academy of Sciences, 106(11), 4133-4137. DOI: 10.1073/ pnas.0812355106

Stokstad, E. (2017). UN biodiversity group confronts cash crunch. Science, 355(6332), 1358. DOI: $10.1126 /$ science. 355.6332 .1358

Turnhout, E., Bloomfield, B., Hulme, M., Vogel, J., Wynne, B. (2012). Conservation policy: listen to the voices of experience. Nature, 488(7412), 454-455. DOI: 10.1038/488454a

van Kleunen, M, Dawson, W., Essl, F., Pergl, J., Winter, M., Weber, E., Kreft, H., Weigelt, P., Kartesz, J., Nishino, M., Antonova, L.A. (2015). Global exchange and accumulation of non-native plants. $\mathrm{Na}$ ture, 525(7567), 100-103. DOI: 10.1038/nature 14910

Vavilov, N.I. (1927). Geographical regularities in the distribution of the genes of cultivated plants. Bulletin of Applied Botany, Genetics and Selection, 17(3), 411-428.

Villamagna, A.M., Murphy, B.R. (2010). Ecological and socio-economic impacts of invasive water hyacinth (Eichhornia crassipes): a review. Freshwater biology, 55(2), 282-298. DOI: 10.1111/j.13652427.2009.02294.x

Viña, A., McConnell, W.J., Yang, H., Xu, Z., Liu, J. (2016). Effects of conservation policy on China’s forest recovery. Science Advances, 2(3), 1-8. p.e1500965. DOI: 10.1126/sciadv.1500965

\section{Działalność Międzyrządowej Platformy Naukowo-Politycznej na rzecz Różnorodności Biologicznej i Usług Ekosystemowych dla zachowania różnorodności biologicznej \\ Streszczenie}

W artykule przedstawiono zwięzłe sprawozdanie dotyczące chronologii oraz działalności Międzyrządowej Platformy Polityki Naukowej w sprawie Różnorodności Biologicznej i Usług Ekosystemowych (IPBES). Organizacja ta przywiązuje szczególną wagę do globalnego stanu różnorodności biologicznej, trendów i aktywności politycznej. Artykuł prezentuje uogólniony obraz rozwoju i osiągnięć IPBES w trakcie jego istnienia. Raporty IPBES ze względu na swoje znaczenie są uznawane i aprobowane na całym świecie. Jednak rozpoznawalny sukces IPBES jest niweczony przez sytuację finansową IPBES. W efekcie istnieje stan, która prowadzi ostatecznie do wniosku, że zawsze następuje hamowanie finansowania wspólnego dobra.

Key words: biodiversity monitoring, ecological assessment, ecological policy, funding, nature conservation

Received: [2017.09.01]

Accepted: [2017.11.13] 